\title{
DESKRIPSI PEMBELAJARAN MATEMATIKA DENGAN METODE SOCRATES DALAM PENDEKATAN KONTEKSTUAL DI SMP
}

\author{
Akbar Taufik \\ Program Studi Pendidikan Matematika, Fakultas Keguruan dan Ilmu Pendidikan \\ Universitas Pancasakti Makassar \\ e-mail: akbar.taufik@unpacti.ac.id
}

\begin{abstract}
ABSTRAK
Masalah dalam peneitian ini adalah bagaimanakah deskripsi pembelajaran matematika dengan metode Socrates dalam pendekatan kontekstual pada siswa SMP Negeri 13 Makassar. Tujuan dalam penelitian ini adalah untuk mendeskripsikan pembelajaran matematika dengan metode Socrates dalam pendekatan kontekstual pada siswa SMP Negeri 13 Makassar. Penelitian ini merupakan penelitian deskriptif kualitatif. Sumber data dalam penelitian ini adalah siswa kelas VIIA SMP Negeri 13 Makassar dalam pembelajaran matematika dengan menggunakan metode Socrates dalam pendekatan kontekstual. Instrument penelitian yang digunakan dalam penelitian adalah lembar observasi dan tes. Hasil penelitian menunjukkan bahwa pembelajaran matematika

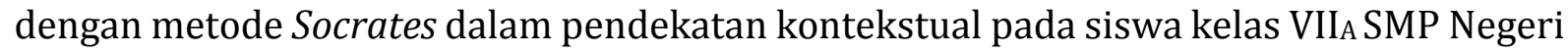
13 Makassar tergolong dalam kategori cukup. Hal ini terlihat dari rata-rata kemampuan pembelajaran matematika siswa kelas VIIA sebesar 65,43 dan kemampuan pembelajaran matematika yang lebih dominan adalah siswa dengan kategori cukup dengan presentase $46,4 \%$ dari 28 siswa.
\end{abstract}

Kata Kunci: Metode Socrates, Pendekatan Kontekstual

\begin{abstract}
The problem in this research is how the description of mathematics learning using the Socrates Method in the contextual approach of students at SMP Negeri 13 Makassar. The purpose of this study was to describe the learning of mathematics by the Socrates Method in the contextual approach of students at SMP Negeri 13 Makassar. This research is a qualitative descriptive study. The source of the data in study this were students of class VIIA SMP Negeri 13 Makassar in learning mathematics using the Socrates Method in a contextual approach instruments Research used in the study were observation sheets and tests. The results showed that the learning of mathematics by the Socrates Method in the contextual approach of class VIIA SMP Negeri 13 Makassar was classified as sufficient. This can be seen from the average mathematics learning ability of Grade VIIA at 65.43 and the more dominant mathematics learning ability is students with sufficient categories with a percentage of $46.4 \%$ of 28 students.
\end{abstract}

Keywords: Socrates Method, Contextual Approach 


\section{A. PENDAHULUAN}

Pendidikan memiliki peranan penting dalam kehidupan manusia, karena dengan pendidikan manusia dapat meningkatkan kualitas dan mengembangkan potensi yang ada pada dirinya. Pendidikan juga dapat membantu manusia menjadi individu yang kreatif, produktif, inovatif, mandiri, dan bertanggung jawab. Hal ini sejalan dengan fungsi dan tujuan pendidikan nasional yang tercantum dalam UU RI Nomor 20 Tahun 2003 pasal 3 yang berbunyi bahwa "Pendidikan nasional yang berfungsi mengembangkan kemampuan dan membentuk watak serta peradaban bangsa yang bermartabat dalam rangka mencerdasarkan kehidupan bangsa, bertujuan untuk berkembangnya potensi peserta didik agar menjadi manusia yang beriman dan bertakwa kepada Tuhan Yang Maha Esa, berakhlak mulia, sehat, berilmu, cakap, kreatif, mandiri, dan menjadi warga negara yang demokratis serta bertanggung jawab."

Berdasarkan tujuan tersebut pendidikan tidak hanya dapat mengembangkan potensi dan kemampuan individu tetapi juga dapat membentuk karakter dan watak individu menjadi lebih baik. Oleh karena itu, setiap individu harus menempuh pendidikan agar dapat meningkatkan kualitas dirinya menjadi lebih baik.

Guna mewujudkan tujuan pendidikan nasional tersebut, dibutuhkan suatu proses pembelajaran pada berbagai bidang studi, salah satunya adalah bidang studi matematika. Matematika perlu diajarkan kepada siswa karena matematika memiliki peranan penting dalam kehidupan sehari-hari. Selain bermanfaat dalam kehidupan sehari-hari, matematika juga berperan dalam mengembangkan pola pikir dan melatih penalaran siswa. Hal ini sesuai dengan tujuan pembelajaran matematika menurut Depdiknas (2006: 346) yang menyatakan bahwa mata pelajaran matematika bertujuan agar siswa mampu memahami konsep matematika dan menjelaskan keterkaitan antar konsep, menggunakan penalaran pada pola dan sifat, memecahkan masalah, mengkomunikasikan gagasan dengan simbol, tabel, diagram, atau media lain untuk memperjelas keadaan masalah, dan memiliki sikap menghargai kegunaan matematika dalam kehidupan. Sementara itu, Santrock (2008: 119) mengatakan bahwa tujuan penting pembelajaran matematika adalah membantu anak memahami konsep. Dengan demikian, pemahaman konsep merupakan hal yang sangat penting dalam pembelajaran matematika.

Dalam memahami konsep tidak hanya terdiri dari unsur kognitif saja, tetapi sikap atau pandangan positif siswa yang muncul dalam proses memahami konsep juga perlu diperhatikan. Hal ini karena sikap dan pandangan positif siswa dalam memahami konsep sangat berpengaruh terhadap proses dan hasil belajar siswa.

Salah satu upaya yang dapat dilakukan untuk mengembangkan pembelajaran matematika siswa adalah menggunakan pendekatan pembelajaran yang tepat. Adapun pendekatan pembelajaran yang dapat diterapkan guru untuk mengembangkan pembelajaran matematika siswa adalah pendekatan konstekstual. Seperti yang disampaikan oleh Kunandar (2007: 296) bahwa pembelajaran dengan pendekatan konstekstual adalah konsep belajar yang membantu guru menghubungkan antara materi pelajaran yang diajarkannya dengan situasi dunia nyata siswa dan mendorong siswa membuat hubungan antara pengetahuan yang dimilikinnya dengan penerapannya dalam kehidupan sehari-hari. Dengan mengaitkan materi pembelajaran dengan kehidupan sehari-hari, siswa dapat mengetahui manfaat dari belajar materi tersebut.

Hal tersebut dapat membuat siswa lebih tertarik untuk belajar matematika dan membuat siswa lebih aktif dalam pembelajaran sehingga pembelajaran matematika siswa pun dapat berkembang. Dimana menurut Kunandar (2007: 305) terdapat tujuh komponen 
utama pembelajaran yang mendasari penerapan pembelajaran dengan pendekatan konstekstual di kelas, salah satu komponen tersebut adalah bertanya. Bertanya merupakan hal yang penting dalam pembelajaran. Melalui kegiatan bertanya, guru dapat menggali informasi, membangkitkan respon, memfokuskan perhatian siswa, dan menguji pemahaman siswa. Selain itu, melalui pertanyaan-pertanyaan yang dilakukan guru, siswa akan lebih termotivasi dan merasa tertantang untuk berfikir menemukan jawaban sehingga pembelajaran di kelas menjadi lebih aktif. Hal ini sejalan dengan yang dikatakan oleh Paul dan Elder (2006: 62), bahwa agar dapat berpikir, seseorang harus berhadapan dengan pertanyaan yang merangsang pemikirannya. Oleh karena itu, dibutuhkan suatu metode pembelajaran yang dapat membantu guru dalam memberikan pertanyaan-pertanyaan kepada siswa.

Salah satu metode pembelajaran yang memuat pertanyaan-pertanyaan dan cara bertanya adalah metode Socrates. Dalam pembelajaran, Jones, Bagford dan Walen (Yunarti, 2011: 47) mendefinisikan metode Socrates sebagai sebuah metode yang menjalankan proses diskusi yang dipimpin guru untuk membuat siswa mempertanyakan validitas penalarannya atau untuk mencapai sebuah kesimpulan. Pada metode Socrates banyak dialog yang menggunakan pertanyaan-pertanyaan yang memandu siswa untuk berpikir dan mengambil kesimpulan. Pertanyaan Socrates yang diajukan membimbing siswa untuk mengontruksi pengetahuannya berdasarkan dialog yang terjadi. Dengan menggabungkan metode Socrates dan pendekatan konstekstual, maka akan menciptakan suatu proses pembelajaran yang menarik minat siswa untuk belajar serta dapat membantu siswa dalam mengkontruksi pengetahuannya akan suatu materi yang diajarkan.

Selain dapat menciptakan pembelajaran yang menarik minat siswa, penggabungan metode Socrates dengan pendekatan konstekstual juga dapat membantu siswa melatih kemampuan pembelajaran matematikanya. Hal ini sejalan dengan hasil penelitian Yunarti (2011: 83), yaitu kolaborasi metode Socrates dan pendekatan konstekstual sangat efektif diterapkan di kelas terutama dalam mengembangkan kemampuan belajar siswa. Melalui pertanyaan-pertanyaan Socrates yang dikaitkan dengan kehidupan nyata sehari-hari, dapat memicu siswa memiliki rasa ingin tahu yang lebih, mencari kebenaran atas pertanyaan tersebut, bersikap sistematis dan analitis dalam menyelesaikan persoalan yang berhubungan dengan dunia nyata, dan lebih percaya diri dalam memahami konsep karena sebelumnya dia telah memiliki memiliki pengetahuan tentang permasalahan nyata tersebut.

Dengan demikian, diterapkannya metode Socrates yang dipadukan dengan pendekatan konstekstual diharapkan dapat mendorong munculnya kemampuan pemahaman belajar matematika siswa. Oleh karena itu, penelitian ini akan mendeskripsikan pembelajaran matematika dengan metode Socrates dalam pendekatan konstekstual.

Tujuan dari penelitian ini adalah Untuk mengetahui deskripsi pembelajaran matematika siswa yang diajar dengan metode pembelajaran Socrates dalam pendekatan konstekstual pada pokok bahasan Harga Pembelian dan Harga Penjualan.

\section{B. METODE PENELITIAN}

Penelitian ini merupakan penelitian kualitatif yaitu prosedur penelitian yang menghasilkan data deskriptif berupa kata-kata tertulis atau lisan dari orang-orang atau perilaku yang diamati dengan cara mengamati, mencatat, bertanya, dan menggali sumber yang memunculkan dalam pembelajaran dengan metode Socrates. 
Subjek dalam penelitian ini adalah siswa kelas VII $_{A}$ SMP Negeri 13 Makassar tahun pelajaran 2019/2020. Banyak siswa di kelas tersebut adalah 30 siswa yang terdiri dari 10 siswa laki-laki dan 20 siswa perempuan. Pengumpulan data dalam penelitian ini dilakukan dengan teknik (1) Observasi, (2) Pemberian tes.

Teknik analisis data yang digunakan dalam penelitian ini ialah dengan menggunakan model Miles dan Huberman (1992: 16) yaitu melalui proses reduksi data, penyajian data, dan penarikan simpulan.

\section{HASIL DAN PEMBAHASAN}

Tabel 1. Matriks pembelajaran matematika siswa

\begin{tabular}{|c|c|c|c|c|}
\hline No & $\begin{array}{c}\text { Tipe } \\
\text { pertanyaan }\end{array}$ & $\begin{array}{l}\text { Contoh } \\
\text { pertanyan }\end{array}$ & $\begin{array}{l}\text { Kemampuan } \\
\text { Pemahaman } \\
\text { Konsep yang } \\
\text { Muncul }\end{array}$ & $\begin{array}{l}\text { Disposisi Pemahaman } \\
\text { Konsep yang Muncul }\end{array}$ \\
\hline 1 & Klarifikasi & $\begin{array}{l}\text { Apa yang } \\
\text { dimaksud } \\
\text { dengan } \\
\text { Aritmetika } \\
\text { Sosial? }\end{array}$ & $\begin{array}{l}\text { Siswa mampu } \\
\text { menjelaskan } \\
\text { pertanyaan } \\
\text { yang yang } \\
\text { diberikan } \\
\text { oleh guru. }\end{array}$ & $\begin{array}{l}\text { Pencarian Kebenaran, Berpikiran Terbuka, } \\
\text { Analitis,Sistimatis, Rasa Ingin Tahu }\end{array}$ \\
\hline 2 & Asumsi & $\begin{array}{l}\text { Apa } \\
\text { sajakah } \\
\text { yang } \\
\text { dipelajari } \\
\text { dalam } \\
\text { materi } \\
\text { Aritmetika } \\
\text { sosial? }\end{array}$ & $\begin{array}{l}\text { Siswa dapat } \\
\text { menjelaskan } \\
\text { dengan benar } \\
\text { tentang soal } \\
\text { yang } \\
\text { diberikan. }\end{array}$ & $\begin{array}{l}\text { Pencarian Kebenaran, Berpikiran Terbuka, } \\
\text { Analitis,Keperca yaan Diri dalam Berpikir, } \\
\text { Rasa Ingin Tahu }\end{array}$ \\
\hline 3 & Alasan & $\begin{array}{l}\text { Bagaimana } \\
\text { anda bisa } \\
\text { tahu kalau } \\
\text { jawaban } \\
\text { anda itu } \\
\text { benar? }\end{array}$ & $\begin{array}{l}\text { Siswa coba } \\
\text { menjelaskan } \\
\text { tentang } \\
\text { jawaban yang } \\
\text { ia jawab. }\end{array}$ & $\begin{array}{lcc}\text { Pencarian } & \text { Kebenaran, } & \text { Berpikiran } \\
\text { Terbuka, } & \text { Analitis,Sistimatis,Kepercayaan } \\
\text { Diri dalam } & \text { Berpikir, Rasa Ingin Tahu }\end{array}$ \\
\hline 4 & Persepsi & $\begin{array}{l}\text { Apakah } \\
\text { perbedaan } \\
\text { Harga } \\
\text { penjualan } \\
\text { dan harga } \\
\text { pembelian } \\
\text { ? } \\
\end{array}$ & $\begin{array}{l}\text { Siswa dapat } \\
\text { menjelaskan } \\
\text { dengan benar } \\
\text { tentang soal } \\
\text { yang } \\
\text { diberikan }\end{array}$ & $\begin{array}{l}\text { Berpikiran Terbuka,Analitis, Kepercayaan } \\
\text { Diri dalam Berpikir, Rasa Ingin Tahu }\end{array}$ \\
\hline 5 & implikasi & $\begin{array}{l}\text { Bagaimana } \\
\text { cara } \\
\text { pengerjaan } \\
\text { soal yang } \\
\text { telah } \\
\text { diberikan? }\end{array}$ & $\begin{array}{l}\text { Siswa dapat } \\
\text { menjelaskan } \\
\text { dengan benar } \\
\text { tentang soal } \\
\text { yang } \\
\text { diberikan }\end{array}$ & $\begin{array}{l}\text { Analitis, Sistimatis, Kepercayaan Diri dalam } \\
\text { Berpikir }\end{array}$ \\
\hline
\end{tabular}


Berdasarkan hasil pengamatan selama proses pembelajaran dengan metode Socrates dalam pendekatan kontekstual yang berlangsung pada pertemuan 1,2,dan 3 di kelas VII-A SMP Negeri 13 Makassar, peneliti menyimpulkan beberapa hal sebagai berikut:

1. Siswa masih kurang aktif pada pertemuan pertama yang terlihat dari belum beraninya siswa mengungkapkan pendapat sebelum ditunjuk oleh guru.

2. Kurang aktifnya siswa pada pertemuan pertama karena sosok peneliti yang masih baru dan belum saling mengenal antara siswa dan guru. Tetapi hal tersebut dapat diatasi dengan cara guru terus memotivasi pada setiap pertemuan dan membawa suasana belajar menjadi lebih santai sehingga pembelajaran dengan metode Socrates dalam pendekatan kontekstual yang memberikan banyak pertanyaan dan permasalahan matematika dari guru tidak menjadikan siswa merasa tertekan.

3. Siswa sudah mulai terbiasa pembelajaran dengan metode Socrates dalam pendekatan kontekstual pada pertemuan selanjutnya meskipun siswa masih terus harus di beri bimbingan yang lebih.

4. Kurang terlihatnya interaksi antarsiswa saat proses pembelajaran. Pertanyaan-pertanyaan yang diharapkan tidak hanya muncul antara guru dan siswa, tetapi juga antara siswa dengan siswa, masih kurang terlihat. Hal tersebut mungkin karena sebagian besar siswa belum bisa menemukan sendiri konsep materi jika tidak dibimbing langsung oleh guru, akibatnya siswa kurang percaya diri ketika harus bertanya atau menjawab pertanyaan guru, terlebih untuk mengajukan pertanyaan sesama siswa.

5. Sebelum memulai pembelajaran, hal peneliti yang anggap penting adalah guru perlu mempersiapkan pertanyaan-pertanyaan yang akan diajukan pada saat pembelajaran, agar memudahkan guru mengembangkan pertanyaan-pertanyaan yang berkaitan dengan pembelajaran dengan metode Socrates dalam pendekatan kontekstual.

6. Menurut peneliti, tujuan dari diajukanya pertanyaan-pertanyaan Socrates oleh guru adalah untuk membimbing siswa dalam menemukan sendiri konsep materi pelajaran yang dapat di kembangkan saat siswa berdiskusi mengerjakan soal dan saat tanya jawab.

7. Pertanyaan-pertanyaan Socrates membuat siswa menjadi lebih aktif dan melatih kemampuan belajar siswa, serta pendekatan kontekstual membuat siswatidak terlalu tegang saat pembelajaran karena siswa dibawa menghubungkan pembelajaran dengan kehidupan nyata.

\section{PEMBAHASAN}

Pembelajaran dengan metode Socrates dalam pendekatan kontekstual adalah pembelajaran yang dapat mengembangkan kemampuan belajar siswa, karena dalam pembelajaran dengan metode Socrates dalam pendekatan kontekstual, guru memberikan banyak pertanyaan-pertanyaan yang membuat siswa untuk berpikir secara jeli dan siswa juga dapat menemukan sendiri konsep pembelajaran matematika.

Menurut teori Socrates, serangkaian pertanyaan dapat membantu siswa menemukan jawaban atas dasar kecerdasan dan kemampuan siswa itu sendiri. Dengan siswa banyak bertanya dan berpikir dalam pembelajaran dengan metode Socrates dalam pendekatan kontekstual, maka siswa akan semakin paham dengan pembelajaran, dan menunjukan hasil belajar yang baik. Dalam pembelajaran dengan metode Socrates dalam pendekatan kontekstual, proses belajar mempunyai peranan penting. Siswa yang aktif dan memperhatikan selama proses pembelajaran dengan metode Socrates dalam pendekatan kontekstual cenderung memiliki hasil pembelajaran yang 
baik. Rute belajar (learning route) dimana siswa mampu menemukan sendiri konsep dan ide matematika. Sebagai konsekuensinya, guru harus mampu mengembangkan pelajaran yang interaktif dan memberikan kesempatan kepada siswa untuk memberikan kontribusi terhadap proses belajar siswa, yang dalam hal ini peneliti memilih Deskripsi pembelajaran dengan metode Socrates dalam pendekatan kontekstual.

Sebelum pembelajaran berlangsung, guru mengkondisikan siswa untuk mengikuti pembelajaran dan diharapkan dapat menimbulkan diskusi antarsiswa yang satu dengan yang lainnya serta membawa suasana belajar yang santai sehingga siswa merasa lebih rileks dalam proses pembelajaran dengan metode Socrates dalam pendekatan kontekstual. Karena biasannya siswa cenderung merasa takut ketika ditanya oleh guru tentang hal-hal yang mereka tidak ketahui jawabannya. Dalam proses pembelajaran inilah diharapkan akan timbul diskusi antarsiswa maupun siswa dengan guru ketika guru mengajukan pertanyaan-pertanyaan yang mendalam.

Di akhir pokok bahasan guru memberikan tes untuk mengukur kemampuan pembelajaran matematika siswa. Berdasarkan tes tersebut, di peroleh skor rata-rata hasil belajar siswa pada pokok bahasan Aritmetika Sosial adalah sebesar 65,43. Dapat diambil kesimpulan bahwa siswa kelas VII-A SMP Negeri 13 Makassar memiliki kemampuan cukup dalam pembelajaran matematika.

Hasil tes kemampuan pembelajaran matematika kelas VII-A SMP Negeri 13 Makassar masuk dalam kategori cukup dan sebagian siswa belum mendapatkan hasil yang memuaskan disebabkan oleh beberapa faktor. Matematika adalah pelajaran yang konsepnya tersusun secara hierarkis dari yang mudah atau sederhana meningkat ke yang sulit atau rumit. Dengan demikian, jika siswa belum menguasai konsep yang mendasar maka siswa akan merasa kesulitan dalam menguasai konsep yang lebih lanjut. Pada umumnya dalam mempelajari pelajaran yang di anggap sulit, siswa cenderung menunjukkan minat belajar dan motivasi berprestasi yang rendah pula. Masih banyaknya siswa yang mendapat skor belum maksimal karena sebagian kelas VII-A masih belum menguasai konsep dasar dalam pembelajaran matematika materi Aritmatika Sosial. Siswa yang belum memahami konsep dasar dalam materi tersebut kemungkinan karena siswa belum memiliki kreativitas dalam berpikir saat proses pembelajaran dengan metode Socrates dalam pendekatan kontekstual berlangsung. Kreativitasdalam berpikir sangat mempengaruhi proses belajar. Belajar diawali dari proses ingin tahu. Ketika seseorang memiliki masalah dan ingin menyelesaikannya , ia akan menggunakan pikirannya untuk melihat fakta-fakta apa saja yang terjadidi sekitarnya yang berhubungan dengan masalah tersebut. Kemudian ia menghubungkan fakta-fakta yang ada lalu berpikir mencari alternatif penyelesaian sehingga nantinya didapatkan penyelesaian yanf diinginkan. Selain karena belum memahami konsep dasar faktor selanjutnya yaitu proses pembelajaran dengan metode Socrates dalam pendekatan kontekstual dan diskusi berlangsung. Berdasarkan hasil pengamatan, terlihat siswa tidak lamban untuk beradaptasi dalam proses pembelajaran dengan metode Socrates dalam pendekatan kontekstual. Hal ini terlihat ketika guru memberikan pertanyaan-pertanyaan, siswa berani untuk menjawab pertanyaan dan berdiskusi dengan baik bersama teman sebangkunya. Namun terdapat beberapa hal kendala selama pembelajaran yaitu ketika guru sedang memberikan pertanyaan-pertanyaan Socrates kepada salah seorang siswa, terkadang siswa lain terlihat kurang memperhatikan, dan waktu yang kurang untuk menghasilkan pembelajaran dengan metode Socrates dalam pendekatan kontekstual secara maksimal. Karena dalam membimbing siswa dengan pertanyaanpertanyaan Socrates, guru banyak memberikan waktu kepada siswa untuk berpikir, terlebih ketika siswa belum mampu menemukan jawaban yang tepat maka guru harus terus membimbing dengan mengajukan pertanyaan-pertanyaan yang lebih khusus untuk mengarahkan siswa 
menjawab pertanyaan dengan benar. Kurangnya waktu karena banyaknya siswa yang harus dibimbing, menyebabkan siswa yang belum memahami konsep dasar dan sulit memikirkan jawaban menjadi belum memahami materi Aritmetika Sosial dengan baik.

Selanjutnya siswa diberikan angket terbuka tentang respon pembelajaran dengan metode Socrates dalam pendekatan kontekstual. Pada umunya siswa menunjukkan respon positif terhadap pembelajaran dengan metode Socrates dalam pendekatan kontekstual yang dilaksanakan. Hampir semua siswa memberikan respon yang positif terhadap pembelajaran dengan metode Socrates dalam pendekatan kontekstual. Umumnya siswa yang aktif dan memperhatikan saat pelajaran dengan metode Socrates dalam pendekatan kontekstual, cenderung memiliki kemampuan pembelajaran yang baik

\section{PENUTUP}

\section{KESIMPULAN}

Hasil penelitian menunjukkan bahwa pembelajaran matematika dengan metode Socrates dalam pendekatan kontekstual pada siswa kelas $\mathrm{VII}_{\mathrm{A}}$ SMP Negeri 13 Makassar tergolong dalam kategori cukup. Hal ini terlihat dari rata-rata kemampuan pembelajaran matematika siswa kelas $\mathrm{VII}_{\mathrm{A}}$ sebesar 65,43 dan kemampuan pembelajaran matematika yang lebih dominan adalah siswa dengan kategori cukup dengan presentase $46,4 \%$ dari 28 siswa.

\section{SARAN}

Berdasarkan kesimpulan di atas, maka peneliti menyarankan hal-hal sebagai berikut: (1) Hasil penelitian ini diharapkan dapat menjadi rekomendasi bagi para guru untuk dapat menguasai dan mempelajari lebih dalam terkait dengan metode Socrates dalam pendekatan kontekstual pada pembelajaran matematika agar kesulitan-kesulitan siswa dapat teratasi. (2) Untuk penelitian yang relevan, agar meneliti kembali deskripsi pembelajaran matematika dengan metode Socrates dalam pendekatan kontekstual yang lebih lengkap, perlu dilakukan verifikasi dengan mengembangkan ke materi-materi pembelajaran matematika lainnya.

\section{DAFTAR ISI}

Departemen Pendidikan Nasional. (2006). Permendiknas nomor 22 tahun 2006 tentang standar isi sekolah dasar. Jakarta: Depdiknas.

Kunandar. 2007. Guru Profesional Implementasi Kurikulum Tingkat Satuan Pendidikan (KTSP) dan Sukses dalam Sertifikasi Guru. Jakarta : Raja Grafindo Persada.

Miles, Matthew B dan Huberman, A. Michael. 1992. Analisis Data Kualitatif. Jakarta: UI-Press.

Paul, R dan Elder L. 2006. Critical Thingking: The Art of Socratic Questioning. Journal of Development Education, 31(1), [62-67].

Santrock J.W. 2008. Psikologi Pendidikan Edisi Kedua. Jakarta: Prenada Media Group.

Undang-Undang Republik Indonesia Nomor 20 Tahun 2003 Sistem Pendidikan Nasional. 8 Juli 2003. Lembaran Negara Republik Indonesia Tahun 2003 Nomor 4301. Jakarta.

Yunarti, Tina. 2011. Pengaruh Metode Socrates terhadap Kemampuan dan Disposisi Berpikir Kritis Matematis Siswa SMA. Disertasi-UPI; tidak diterbitkan. 